\title{
Observation of the Japanese Consciousness of Beauty by Kigo Study
}

\author{
Shen Wen' ${ }^{\text {a }}$ \\ ${ }^{1}$ Jiangxi college of foreign studies,NanChang,330099, China \\ ashenwen@yeah.net
}

Keywords: Kigo; Haiku; Consciousness; Beauty; Religious customs

\begin{abstract}
Season language is the soul of haiku. The natural geographical environment and traditional farming production make the Japanese nation forms the genesis of life, cultural psychological structure of the nation that bears a unique way of thinking, emotions, values and aesthetic appeal in depth. Kigo in haiku implies the natural aesthetics that Japanese people interact with nature communion, which conveys the profound nature of the Japanese people's unique aesthetic view and philosophy of language likes season's word.
\end{abstract}

\section{Introduction}

Haiku is a traditional form of Japanese literature rhyme, it is not only the shortest metrical poetry in the world's literature, but also is unique to Japanese Literature Poetry. Traditional haiku requires seventeen syllables, as かとにま つははたちあふ よちいさし.

This haiku is to the effect that: before the door stand tall sunflower, old mother stand still under it, expecting the child back, I am so eager to go home. In addition, the haiku also requires the existence of a season word. Kigo is an important factor in the haiku sentence, it is like "Poetry eye" in the poem, which is the key to understanding haiku. So, in this first sentence of haiku, kigo is "Li Kui”, a kind of ornamental flowers. Because Sunflower open in the summer, it is language summer season. The so-called quaternary language refers to the haiku sentence and four seasons Changes related natural phenomena, scene; traditional festivals, anniversaries and ceremonial activities relating thereto, its subject matter and the scope is very broad. Since the Japanese living in the island with significant season's changes, and seasonal changes and life are closely related. Language in which multicolored natural environment, intimacy and delicate observation of naturally occurring, sensibility is granted. [1]As pointed out by many Japanese authors, Japan's unique natural environment makes the Japanese and nature forged a bond. It is also in this terror, this nature, the Japanese spirit and life, art and religion was born. Therefore, since ancient times, Japanese people have a natural scene perception of life, observe the traditional human thinking. The kigo haiku sentence can be seen as the unique artistic expression of the Japanese perception of nature as well as keen and deep feelings.

\section{Origin and naming of haiku}

Haiku have a specific format, respectively, formed by three non-rhyming verse five, seven and five syllables, and constituted a total of 17 pronunciations. Its first sentence pentameter, called First sentence, second sentence Qiyin, third sentence is the end of the pentameter, called knot sentence. Haiku creation generally follows a basic rule: haiku sentence generally have a season word. Season language refers to represent spring, summer, autumn and winter seasons and term of the New Year. 
In the quarter, in addition to language "Summer Showers", "Snow" and other manifestations of climate terms, there are like "cherry", "cicada" and other animal and plant names. In addition, as "lucky money", "yangchunmian" such customs are also many applications. "Kigo" modern Japanese people usually take a sentimental attachment for one young age or hometown nostalgia. Occasionally there is no law and freedom season haiku. No quarter haiku, Gu name Incredibles, is not kigo haiku sentence. Law is completely free haiku haiku format even gave up. Haiku is elegant, antique-style poetry, inherited the traditional Japanese aesthetic consciousness. Japan emerged when medieval and song and the song format is five thirty-one tone. After the song was chanted because many people together, even the song of long length the appeared. And even haiku originated in the song, the song is made by sentences for three seventeen tone. [2]Even songs flank sentence for two fourteen tone. Add up, it is exactly thirty-one tones. Japanese song people Masaoka Shiki (1867 1902) said that the formation of haiku thanks to Chinese Modern Style Poems quatrains. He said: haiku, and song, although they are different forms of Chinese poetry, but the same sense of fun, which in particular similarities between haiku and Chinese poetry and more, thanks to the Gein Haiku Poems of it.

Haiku mood is "natural", "fresh", "quiet", "fresh", "idle silence", "unseen", "ethereal" Beauty, having more common with Poetry. The beauty of haiku is that it associates the natural scenery and poets recite "idle silence" with the mood, to create a single thread times past, a unique "finish" beauty. This kind of "idle silence" is also repeatedly reflected in Chinese poetry, such as Wang Wei's Poems.

\section{Expression way of Kigo}

Season language is widely used in Japan, which is not only widely used in daily greetings, but also widely used in correspondence. In addition, the Japanese literary works, especially in haiku the Kigo is more extensively used.

\subsection{In daily greeting,}

Japanese often talks from the season, weather as an issue. Such as: よく降りますね; やっと春 らしくなりましたね。. It is not hard to see that the Japanese takess the season as main topics in greetings.

\subsection{In the letter}

The specification of Japanese letter often starts from kigo, which is typical Japanese writing habit. Season words of Japanese have both traditional fixed expression Chinese vocabulary, and flexible way change according to the actual season.

(1) Fixed Kigo vocabulary

$\ulcorner$ 新春の候 $「$ 厳冬の候」「春寒の候」「早春の候值此早春时候」「春暖の候 $\ulcorner$ 陽春の候」「新 緑の候」「初夏の候」「盛夏の候」「炎暑の候」「残暑の候」「初秋の候」「秋涼の候」「晚秋の

\section{候」「寒冷の候」}

(2) Change according to the practical experience of season

This class often change according to the actual feeling, season, weather, its expression is very specific. Such as:

「これからの季節、朝夕は冷え込みますので、くれぐれもご自愛ください」 
「謹んで残暑お見舞いを申し上げます. 残暑とは名のみにて、連日盛暑にも劣らぬ暑さが 続いておりますが、皆様には如何お過ごしでしょうか」

\subsection{In the literature}

In Japanese literature, nature is always an important topic. One of the two stars Japanese ancient essays of the "pillow" open it's a description with the four seasons, with extreme euphemism tone depicts the appeal of Japan's four seasons.「春はあけぼの。やうやうしろくなりゆく山ぎは、 すこしあかりて、紫だちたる雲のほそくたなびきたる。夏は夜。月のころはさらなり。闇 もなほ蛍のおほく飛びちがひたる。またーつニつなどほのかにうち光りてゆくもをかし。 雨など降るもをかし。秋は夕暮れ。夕日のさして、山の端いと近うなりたるに鳥の㾛どこ ろへ行くとて、ニつ三つなど飛びいそぐさえあわれなり...冬はつとめて。雪の降りたるは いふべきにもあらず...」 The writer condensed the seasonal changes in the most representative scenery, making the person has the feeling of immersive.

\section{Rhetorical analysis of Kigo}

Season's word about the spring season is selected to briefly illustrate the season Language from three categories.

4.1 The use of metaphor. Lakoff \& Johnson (1980) pointed in the "cognitive approach to metaphor" that metaphor is universal, systematic, and conceptual. Lakoff use the source domain and the target domain mapping and image schema to explain metaphor. He believes that the essence of metaphor is to experience one thing by other things. Metaphors are more common in Kigo. Take several look at the following expression.

(1) 春浅し

(2) 斑雪

\section{（3）花の雲 花屑 花吹雪 花笺}

浅 $い$ in the first season's word is to show the degree from the surface to the end portion of the word, but is used here to express the depth of specific school of life look hazy early spring. The soft look of spring is quietly manifested.

The second word use a metaphor 斑 to describe the legacy of the early spring snow. Like markings added to the earth, which makes it full of life suddenly, and making people to image.

Words in the third group are all flowers for the prototype metaphor. The first is meant to open full cherry trees, arranged in rows, distance, layer upon layer, as if the sky clouds in general. Refers cherry gradually lost, wandering petals as a "crumbs" showing its vivid image. South monsoon, blowing withered petals of cherry blossoms, hovering in the air again elegant dance floor, like most of the winter wind and snow scene, so its figurative metaphor is evident. Finally, refers to the 
scattered petals into the water, he gave her as a small raft, the poetic word formation is comparable Bing pen "small paper boats" of the.

4.2 Synecdoche way. Synecdoche metaphor is equally common figures of speech, synecdoche is "the expression of general semantics vocabulary to express more specific semantics vocabulary, or contrary thereto, expressing special semantic vocabulary to express the semantics of general vocabulary," which refers to the kind of relationship with the species. Let us look at some of the following synecdoche performance.

(1)木の芽流し

\section{(2)花の雨}

Example one is the long-time rain in early spring when the buds of trees took. Long rain season spring contains a lot of things, but people just choose the state in early spring buds to depict the early spring image vividly, as if the rain sprinkled on points before the buds scenery at hand. Example Two is about cherry blossoms nowadays rain and overcast weather when the cherry blossoms. The rainy days of early spring, but it is difficult to give it a qualitative definition. Then the Japanese open with cherry representative to show climate characteristics, features prominent, left to the reader's imagination fully, greatly increasing the performance of interest.

4.3 Personification. Anthropomorphic rhetoric is to things other than humans, that is, animals, objects, abstract concepts proposed to a human expression. [3]Look at the following two groups of anthropomorphic performance.

\section{(1)山笑い 山眠い}

\section{(2)夏隣}

First, describe the vegetation began to germinate in the spring, spring hill sunny state. The spring hill is described as the shy smile that in the spring, the beauty of spring is immediate shown in the mind; at the same time, the word in the latter describes the bleak winter as in quiet sleep, the kind of winter quiet and depression also come to mind, showing a net creator of nature affectionate, and delicate soul.

Second, the performance of late spring, summer coming words. The word is to show tangible object next to the mean. But summer is not the shape of the function words. Here the use of the "neighbor", which in a way is the summer as a living body, can close, either you can stay away from.

\section{Beauty consciousness implied in Haiku}

5.1 Metaphor Role: This refers to the specific images by analogy, to indicate the author's feelings, and express affection in order to achieve the objective and subjective visual depictions of unity. Take the haiku of Yamaguchi Seishi for example:

\section{うしろょ 见る春水の去 ゆくを}

As explained by the famous haiku writer that the river flows downstream through the rapids from upstream. "Spring water" here has changed from a simple scene where language becomes emotionally charged images. The author use "spring water" to imply the emotion that "spring is about gone, only the laggards feel can not keep up the situation." By reading this sentence, people naturally think of such a state in "Analects" that "people stand beside the river and say that time 
runs like the water ......." On dissolved in season phrase "spring water," the sensual image of their emotions, the author create a new realm of art, at the moment, "Spring water" and haiku are into an organic whole, enhancing the image of haiku and artistry.

5.2 Symbolic role: To show author of aesthetic experience and emotional inclination by borrowing something concrete to show something special. [4]As Kawabata said, it is by the things of nature that I feel. In other words, the object is nature, which is the symbolism body that trigger thinking, feeling it's inherent. Like Japan critic analysis: Before the Pacific War, the Japanese militarists carried out brutal aggression, brutal internal repression and deprived the people of their freedom of speech, the whole Japanese society in silent situation. The author is the witness of this situation, in haiku sentence with the general frog different, usually remain silent "Twilight," the natural objects as kigo, to symbolize the policy of militarism under high pressure, was forced to endure, no one outspoken Japanese people. Author use "Twilight," the visual imagery to evoke the association of people. This selection with a symbolic imagery or figurative and "to evoke diverse universe", is haiku subtleties. The effect is to make the image in haiku more prominent, meaning richer, clearer mood.

However, whether it is a metaphor, or symbol, they are some kind of associated with the association. In general, the complete works of art are always inseparable association. Association is perception, the concept of memory, thinking, and imagination and so on.

\section{Summary}

As the German linguist Hong Baote said that nature of language is natural result of continued administration of influence by the national spirit characteristics. People from different nation are always tend to understand the general meaning of the word in unique way, add the same meaning and the same emotional colors to the word, couple concept, organize their thoughts in the same direction, and create languages within the scope of national intelligence and originality understanding. So, every language can be inferred associated with the national character. By summarizing the season's word, especially from the description of the spring season in the language, the author pointed it out that there are many manifestations of rhetoric, like the image of Japanese culture to describe the evident. Metaphor use reflects its unique cultural and social way of thinking. The plants, animals in Japanese island natural environment are often become metaphors object. From it, we can see the unique Japanese national ideology of natural and cultural concept of aesthetic ideas.

\section{References}

[1] Matsuo Basho. Japanese translation of waiting Ringling classical haiku [M] Beijing: Hunan People's Publishing House, 2012.

[2] Akamatsu. Limang translated haiku selected sub [M] Beijing: China Friendship Publishing Company, 2014.

[3] Pen Enhua. History of Japanese haiku Pengen Hua [M] Shanghai: Academia Press, 2013.

[4] Matsuo Basho. Classical Japanese haiku poems complication [M] Shijiazhuang: Huashan Literature and Art Publishing House, 2015. 